\title{
Quality of Life and Metabolic Syndrome in Brazilian quilombola communities: A Cross- sectional Study
}

\section{Open acess}

\begin{abstract}
${ }^{1}$ Laboratório de Epidemiologia e Análise de Dados, Faculdade de Medicina do ABC, Santo André, Brasil.
\end{abstract}

${ }^{2}$ Universidade Federal de Tocantins (UFT) - Palmas (TO), Brasil.

${ }^{3}$ Laboratório de Análises Clínicas da Faculdade de Medicina do ABC.

\begin{abstract}
${ }^{4}$ Discente de Medicina na Faculdade de Santa Maria. Cajazeiras, PB, Brasil.
\end{abstract}

${ }^{5}$ Bolsa Produtividade em Pesquisa (CNPq no 309579 / 2015-5).

\section{Corresponding author:}

luiz.sousa@fmabc.br

Manuscript received: April 2018

Manuscript accepted: October 2018

Version of record online: November 2018
Luiz Vinicius de Alcantara Sousa', Erika da Silva Maciel², Fernando Rodrigues Peixoto Quaresma ${ }^{2}$, Ana Carolina Gonçalves de $\mathrm{Abreu}^{4}$, Laércio da Silva Paiva ${ }^{1}$, Fernando Luiz Affonso Fonseca ${ }^{3}$, Fernando Adami ${ }^{1,5}$

\begin{abstract}
Introduction: The lifestyle of quilombola communities has changed due to extra community influence, thus affecting their environmental and behavioral factors related to the Metabolic Syndrome (MS). However, little is known about the influence of MS on the Quality of Life (QoL) of quilombola residents.
\end{abstract}

Objective: We aimed to study the association between MS and QoL in quilombola communities in northern Tocantins, Brazil.

Methods: The QoL of 147 adults from five quilombola communities from Tocantins was assessed using the WHOQOLBREF instrument. Blood pressure, abdominal perimeter, fasting blood glucose, triglycerides and HDL-cholesterol were measured, and the presence of MS was defined as the alteration of at least three of these clinical aspects. The association of the clinical components and the SM presence with the Quality of Life was evaluated by Student's t-test for independent samples.

Results: We observed that in the total population, an altered abdominal perimeter had an inverse association with both the Physical (15.2 vs. $14.0, p=0.002$ ) and General QoL domains (14.4 vs. 14.0, $p=0.045$ ), and MS was inversely associated with the Physical domain (14.9 vs. 14.0, $p=0.030)$. When stratified by sex, the altered abdominal perimeters in men were inversely associated with the Physical (16.5 vs. $14.4, p<0.001)$, Environmental ( 14.0 vs. $12.6, p=0.020)$ and General domains (15.5 vs. 14.0, $p<0.001$ ). MS had an inverse association with the Physical (15.8 vs. $14.4, p=0.026)$ and General domains (14.8 vs. $14.0 p=0.042$ ) in men. In women there was no association between any risk factor studied and QoL domain.

Conclusions: The status of MS was negatively associated with the quality of life of the male population, highlighting the abdominal perimeter, which influences the Physical and General domains of QoL, but in the female population the MS does not interfere in the perception of QoL. Understanding the relationship between chronic diseases and QoL in quilombola communities is necessary to reduce health inequalities in historically vulnerable communities.

Keywords: Quilombolas, quality of life, metabolic syndrome, WHOQOL-BREF. 


\section{INTRODUCTION}

In Brazil, there are 2,648 certified quilombola communities, the majority of which are located in the northeast region of the country ${ }^{1}$. They are formed by groups that have their own identity and are comprised of black descendants of slaves ${ }^{2}$. They are examples of resistance to the history of social exclusion suffered by the black population in Brazil ${ }^{3}$.

Discussions about ethno-racial groups are becoming increasingly common in community health research $^{4-6}$, and bring with them a careful analysis of how ethnicity is interpreted in the health-disease process ${ }^{5,6}$. When referring to the health of the black population, it is necessary to consider the special conditions of vulnerability these communities experience4; this population generally resides in rural areas, which presents a relative degree of geographic isolation, as well as social and health inequalities ${ }^{6}$.

The Quality of Life (QoL) evaluation, although a complex and essential component, presents difficulties, mainly because there is no universally accepted definition of QoL. However, it is possible to use the concept proposed by the World Health Organization (WHO), which defines an individual's QoL as a self-perception of their position in life, taking into account the cultural context, the values system in which they live, and their expectations and concerns ${ }^{7,8}$. The World Health Organization (WHO) developed an instrument for measuring this quality of life, termed the WHOQOL-BREF. This instrument divides QoL into four broad domains: physical health, psychological health, social relationships, and the environment.

The presence of risk factors or disease has a direct or indirect influence on an individual's QoL. An example of this is the chronic non-communicable disease Metabolic Syndrome (MS). This is characterized by a set of cardiovascular risk factors usually related to central fat deposition and insulin resistance, with a complex etiology that is not fully understood but possibly the result of interactions between genetics, metabolism, environmental, and behavioral factors ${ }^{9,10}$.

In the general population, MS has a negative relationship with QoL, particularly with the Physical domain $^{11-13}$. However, population surveys on living and health conditions in quilombola communities are still rare, and little is known about the influence that MS may have on the QoL of its inhabitants. Therefore, this study aimed to examine the association between $\mathrm{QoL}$ and the presence of MS in quilombola communities in northern Tocantins.

\section{METHODS Study Design}

An observational cross-sectional study was carried out in quilombola communities located in the state of Tocantins, Brazil.

\section{Study area}

Quilombola communities in the following regions were included in this study: Córrego Fundo, Manoel João, and Malhadinha communities, located in the rural area of the Municipality of Brejinho de Nazare $(113 \mathrm{~km}$ from Palmas, capital of Tocantins); Barra da Aroeira, located in the city of Santa Tereza do Tocantins $(84 \mathrm{~km}$ from Palmas); and Morro de São João, which is in the municipal boundaries of Santa Rosa do Tocantins $(168 \mathrm{~km}$ from Palmas). All communities are located in the Central Region of the state of Tocantins ${ }^{14-17}$.

\section{Sample size}

Sample collection was difficult because the communities were located in rural areas with limited access, and because they had different cultures. However, the survey consisted of 220 quilombola families, 277 of whom were residents. Of the participants of the survey, 198 were adults (18 years of age or older). This study comprised 147 adults for whom we collected data on their abdominal perimeter, blood pressure, fasting glycemia, triglycerides, and serum HDL cholesterol, and who answered the WHOQOL-BREF questionnaire.

\section{Data collection}

Data were collected between October 2015 and September 2016. To measure QoL, the WHOQOL-BREF instrument was used, which has good internal consistency, discriminant validity, concurrent validity, content validity, and test-retest reliability ${ }^{18}$. The instrument consists of 26 questions: two general questions and 24 that correspond to the 24 facets of the WHOQOL-100. The WHOQOL-100 is the original instrument that assesses an individual's QoL across four domains: physical health, psychological health, social relationships, and environmental relations ${ }^{19,20}$. Their score follows a five-point Likert scale, in which the respondent points out their degree of agreement with the assertion ${ }^{18}$. The instrument is composed of self-applied items, however, it was performed with the subjects in a face-to-face interview. The WHOQOL-BREF calculation follows the WHOQOL Group ${ }^{21,22}$ guidelines, described below:

- It is checked if all 26 items were filled with Likert scale values (from one to five);

- All inverted-scale items are inverted (items three, four, and 26);

- Domain scores are calculated by averaging the facets that make up each domain. In domains composed of up to seven facets, the domain calculation is invalidated if the number of facets answered is not equal to or greater than two;

- In domains composed of more than seven items, the score is not calculated if the number of unanswered facets is equal to or greater than three. The result is multiplied by four, being presented on a scale of four to 20 ;

- Respondents who failed to complete more than six questions ( $80 \%$ of total instrument items) are excluded from the sample.

An aneroid sphygmomanometer and a stethoscope were used to measure the participants' blood pressures. At the time of collection, recommended care was taken in the VII Brazilian Hypertension Guideline ${ }^{23}$, with the participant, who should be in a sitting or lying position, 
resting for three to five minutes before their blood pressure was taken with their arm at $45^{\circ}$ and at the level of the heart. The cuff was placed over the naked arm, localizing the brachial artery, and a mean blood pressure calculated from two measurements taken 30 seconds apart ${ }^{23}$.

In order to obtain measurements of the abdominal perimeter, an anthropometric tape of the Sanny brand was used. Abdominal perimeters were measured by placing the tape around the abdomen between the last rib and the iliac crest $^{24,25}$. Reference values according to ethnicity and sex were defined by the Brazilian Association for the Study of
Obesity and Metabolic Syndrome ${ }^{26}$, which describes the measurement of the abdominal perimeter of Europídeos, South Africans, Western Mediterranean and Middle Easterns with lower recommended values of $94 \mathrm{~cm}$ for males and $80 \mathrm{~cm}$ for females ${ }^{26}$.

Participants were instructed to fast for between eight and 10 hours, and subsequently $5 \mathrm{ml}$ of blood was collected by venipuncture. With this material, glycemia, triglycerides, and HDL cholesterol were analyzed using an enzymatic colorimetric method, and classified according to the diagnostic parameters for $\mathrm{MS}^{25}$ (Chart 1).

\begin{tabular}{|ll|}
\hline \multicolumn{1}{|c|}{ Components } & Levels \\
Men & \\
Women & $>94 \mathrm{~cm}$ \\
Triglycerides & $>80 \mathrm{~cm}$ \\
& $\geq 150 \mathrm{mg} / \mathrm{dl}$ \\
Men & \\
Women & $<40 \mathrm{mg} / \mathrm{dl}$ \\
Blood pressure & $<50 \mathrm{mg} / \mathrm{dl}$ \\
Fasting glycaemia & $\geq 130 \mathrm{mmHg}$ or $\geq 85 \mathrm{mmHg}$ \\
I Brazilian Guideline for Diagnosis and Treatment of Metabolic Syndrome. Brazilian Archives of Cardiology ${ }^{23}$.
\end{tabular}

Chart 1: Predictive values for MS according to the I Brazilian Guideline for Diagnosis and Treatment of Metabolic Syndrome.

MS is a complex disorder, represented by a set of factors of metabolic origin, related to central fat deposition and insulin resistance. To be diagnosed with MS it is necessary to have a combination of at least three of the clinical characteristics: central obesity (high abdominal perimeter), hypertension, fasting hyperglycemia, hypertriglyceridemia, or reduced HDL cholesterol ${ }^{26-29}$.

Data were collected by previously trained staff to avoid possible biases in the collection; the measurement of clinical data was performed by the same researchers in all communities. The data were subsequently manually entered into a database using double-typing to ensure data consistency. This was then validated by a third researcher to ensure accuracy prior to analysis.

\section{Statistical analysis}

Descriptive analysis of qualitative data was performed by presenting both the absolute and relative frequency values. For the quantitative variables, medians were calculated along with their respective 25 th and 75 th percentiles (interquartile range - IIQ). Alternatively, mean values were calculated with their $95 \%$ confidence intervals $(\mathrm{CI})$.

To analyze the association of QoL with clinical factors and MS, according to sex in quilombola communities, a Student's t-test was used for independent samples, with differences considered significant for p-values $\leq 0.05$. Bonferroni's correction was performed for both the general population and comparing the sexes, dividing the original level of significance by the number of tests (30 tests, $p$-value $\leq 0.002$ ). Stata version 11.0 was used in all analyses.

\section{Ethical aspects}

To recruit individuals, meetings were held with the leaders of the quilombos, explaining what the study would look like, when the study would take place, and what benefits the communities would have.

The work in the communities began only after agreement of the Term of Free and Informed Consent, which explained the research and respected the rights of privacy and autonomy of all participants. The present research obtained ethical appreciation (CAAE: 56954116.2.0000.5516).

\section{RESULTS}

A total of 147 adult quilombolas were included in the study, of which $90(61.2 \%)$ were female and 57 $(38.8 \%)$ were male. The participants included 89 (60.5\%) black residents, and participants had a median age of 50 years (IIQ $=35-58)$ (Table 1).

When assessing clinical factors, 72 (48\%) participants had systemic arterial hypertension, and the community of Malhadinha stood out with the highest number of hypertensive $(n=25,36.8 \%)$, and hyperglycemic $(\mathrm{n}=28,41.2 \%)$ participants, and with the highest levels of triglycerides $(\mathrm{n}=9,13.2 \%)$, HDL $(\mathrm{n}=53,77.9 \%)$, and abdominal perimeter were altered (Table 1).

Regarding QoL, the overall mean score across the total population was 14.1 (95\% CI: 13.9-14.5), ranging from 13.2 to 14.7 among the communities. The Environmental domain had the lowest score, both in each community, and in the total population, with a mean of 12.7 (95\% CI: 12.3-13.0) (Figure 1). 
Table 1: Characterization of the quilombola communities studied.

\begin{tabular}{|c|c|c|c|c|c|c|}
\hline Variables & Total & $\begin{array}{l}\text { Barra do } \\
\text { Aroeira }\end{array}$ & $\begin{array}{l}\text { Córrego } \\
\text { Fundo }\end{array}$ & $\begin{array}{c}\text { Morro } \\
\text { de } \\
\text { S. João }\end{array}$ & $\begin{array}{l}\text { Manoel } \\
\text { João }\end{array}$ & Malhadinha \\
\hline & $(n=147)$ & $(n=19)$ & $(n=22)$ & $(n=23)$ & $(n=15)$ & $(n=68)$ \\
\hline & n (\%) & n (\%) & n (\%) & n (\%) & n (\%) & n (\%) \\
\hline \multicolumn{7}{|l|}{ Sex } \\
\hline Female & $90(61.2)$ & 15 (78.9) & $14(63.6)$ & $13(56.5)$ & $9(60.0)$ & 39 (57.3) \\
\hline Male & $57(38.8)$ & $4(21.1)$ & $8(36.4)$ & $10(43.5)$ & $6(40.0)$ & $29(42.7)$ \\
\hline \multicolumn{7}{|l|}{ Ethnicity } \\
\hline White & $7(4.8)$ & $2(10.5)$ & - & $1(4.3)$ & $1(6.7)$ & $3(4.4)$ \\
\hline Black & $89(60.5)$ & $11(57.9)$ & $16(72.7)$ & $14(60.9)$ & $6(40.0)$ & $42(61.7)$ \\
\hline Brown & $43(29.2)$ & $4(21.1)$ & $5(22.7)$ & $5(21.7)$ & $7(46.6)$ & $22(32.4)$ \\
\hline Yellow & $1(0.7)$ & $2(10.5)$ & - & $1(4.4)$ & - & $1(1.5)$ \\
\hline Indigenous & $7(4.8)$ & $2(10.5)$ & $1(4.6)$ & $2(8.7)$ & $1(6.7)$ & - \\
\hline \multicolumn{7}{|l|}{ Pressure } \\
\hline Not & 75 (51.1) & $6(31.6)$ & 7 (31.8) & $11(47.8)$ & $8(53.3)$ & $43(63.2)$ \\
\hline Yes & $72(48.9)$ & $13(68.4)$ & $15(68.2)$ & $12(52.2)$ & $7(46.7)$ & $25(36.8)$ \\
\hline \multicolumn{7}{|l|}{ Glycemia } \\
\hline Not & $85(57.8)$ & $16(84.2)$ & $15(68.2)$ & $5(21.7)$ & $9(60.0)$ & $40(58.8)$ \\
\hline Yes & $62(42.2)$ & $3(15.8)$ & $7(31.8)$ & $18(78.3)$ & $6(40.0)$ & $28(41.2)$ \\
\hline \multicolumn{7}{|l|}{ Triglycerides } \\
\hline Not & 122 (82.9) & 15 (78.9) & $18(81.8)$ & $19(82.6)$ & $11(73.3)$ & $59(86.8)$ \\
\hline Yes & $25(17.1)$ & $4(21.1)$ & 4 (18.2) & $4(17.4)$ & $4(26.7)$ & $9(13.2)$ \\
\hline \multicolumn{7}{|l|}{ HDL } \\
\hline Not & $59(40.1)$ & $10(52.6)$ & $17(77.3)$ & $11(47.8)$ & $6(40.0)$ & $15(22.1)$ \\
\hline Yes & 88 (59.9) & $9(47.4)$ & $5(22.7)$ & $12(52.2)$ & $9(60.0)$ & 53 (77.9) \\
\hline \multicolumn{7}{|l|}{ Abdominal } \\
\hline Not & 73 (49.7) & $8(42.1)$ & $6(27.3)$ & $13(56.5)$ & $6(40.0)$ & $40(58.8)$ \\
\hline Yes & $74(50.3)$ & $11(57.9)$ & $16(72.7)$ & $10(43.5)$ & $9(60.0)$ & $28(41.2)$ \\
\hline \multicolumn{7}{|l|}{$\begin{array}{l}\text { Metabolic } \\
\text { syndrome }\end{array}$} \\
\hline Not & $98(66.7)$ & $11(57.9)$ & $16(72.7)$ & $15(65.2)$ & $9(60.0)$ & $47(69.1)$ \\
\hline \multirow[t]{2}{*}{ Yes } & 49 (33.3) & $8(42.1)$ & $6(27.3)$ & $8(34.8)$ & $6(40.0)$ & 21 (30.9) \\
\hline & Med (IIQ) & Med (IIQ) & Med (IIQ) & Med (IIQ) & Med (IIQ) & Med (IIQ) \\
\hline Age (years) & $\begin{array}{c}50.0 \\
(35.0-58.0)\end{array}$ & $\begin{array}{c}48.0 \\
(28.0-56.0)\end{array}$ & $\begin{array}{c}50.0 \\
(45.0-60.0)\end{array}$ & $\begin{array}{c}51.0 \\
(39.0-56.0)\end{array}$ & $\begin{array}{c}56.0 \\
(47.0-67.0)\end{array}$ & $\begin{array}{c}49.0 \\
(30.0-57.5)\end{array}$ \\
\hline $\begin{array}{l}\text { Abdominal } \\
\text { perimeter }(\mathrm{cm})\end{array}$ & $\begin{array}{c}88.0 \\
(80.0-97.0)\end{array}$ & $\begin{array}{c}89.0 \\
(81.0-103.0)\end{array}$ & $\begin{array}{c}94.0 \\
(87.5-110.0)\end{array}$ & $\begin{array}{c}88.0 \\
(82.0-99.0)\end{array}$ & $\begin{array}{c}93.0 \\
(90.0-103.0)\end{array}$ & $\begin{array}{c}85.5 \\
(77.5-93.5)\end{array}$ \\
\hline
\end{tabular}

Med. Median. IIQ: interquartile range. 

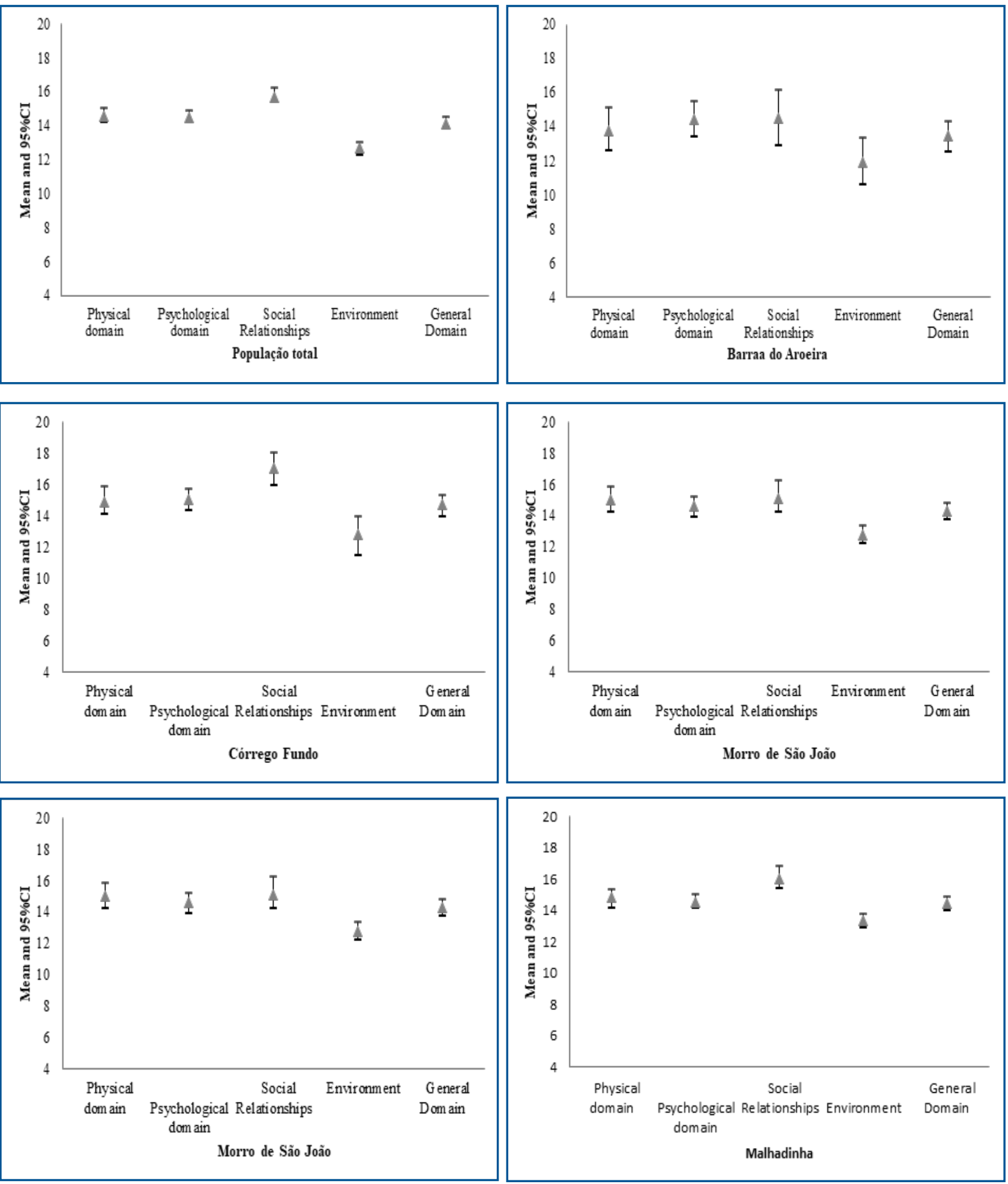

Figure 1: Mean of the WHOQOL-Bref questionnaire domains in all quilombos of the study and stratified by community.

When assessing the relationship between QoL and clinical factors, there was an association between altered abdominal perimeter and lower scores in the Physical and General QoL domains $(\mathrm{p}=0.002$ and $\mathrm{p}=$ 0.045 , respectively). The presence of MS was associated only with lower scores in the Physical domain $(p=0.030)$ (Table 2).

By stratifying the population by sex, it was observed that women's QoL was not associated with clinical factors or the status of MS (Table 3). However, in the male population, the abdominal perimeter was associated with lower scores in the Physical $(\mathrm{p}<0.001)$, General QV $(p=0.042)$ and Environmental $(p=0.020)$ domains. The presence of MS was related to lower scores in the Physical $(p=0.026)$ and General QV $(p=0.042)$ domains of QoL of men (Table 4). 


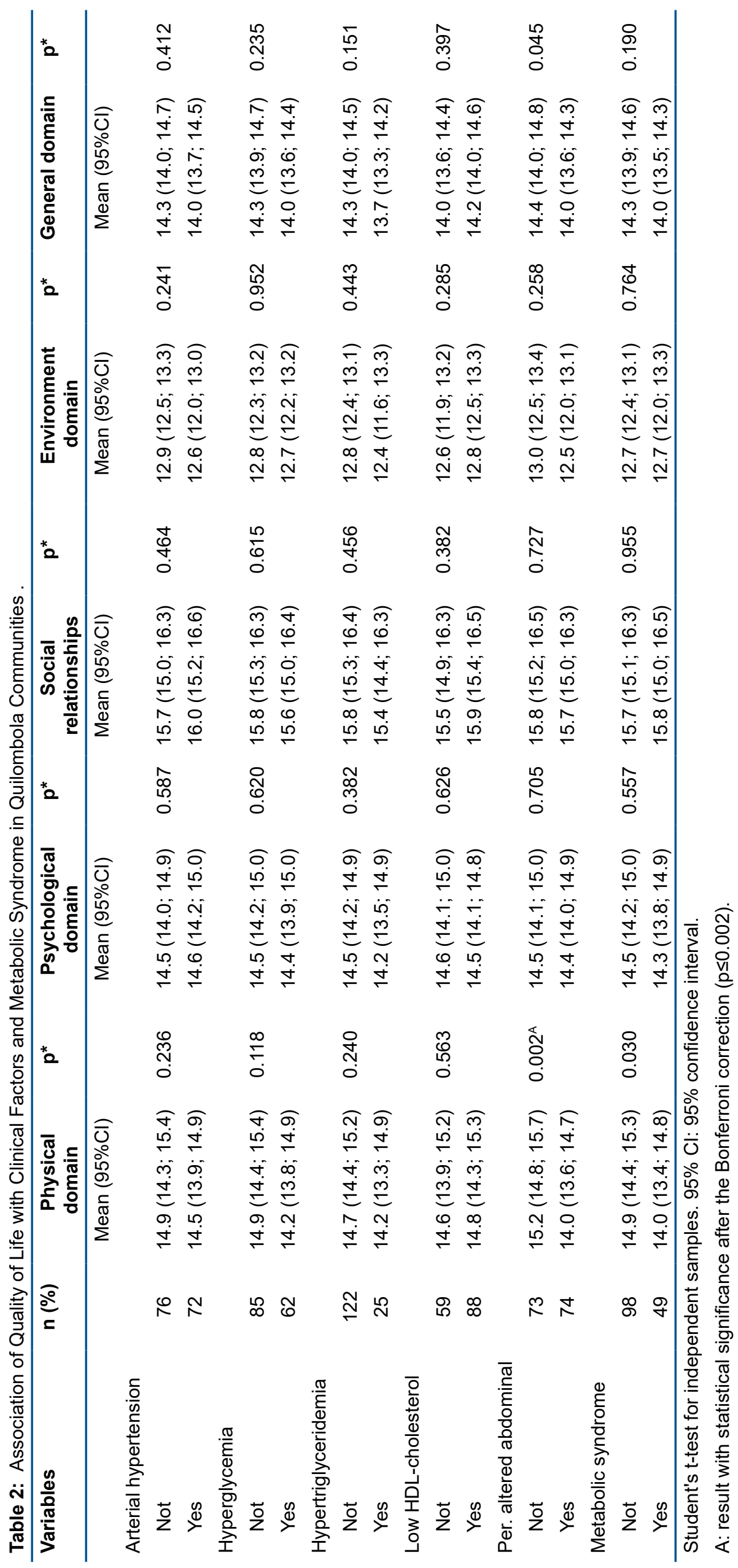




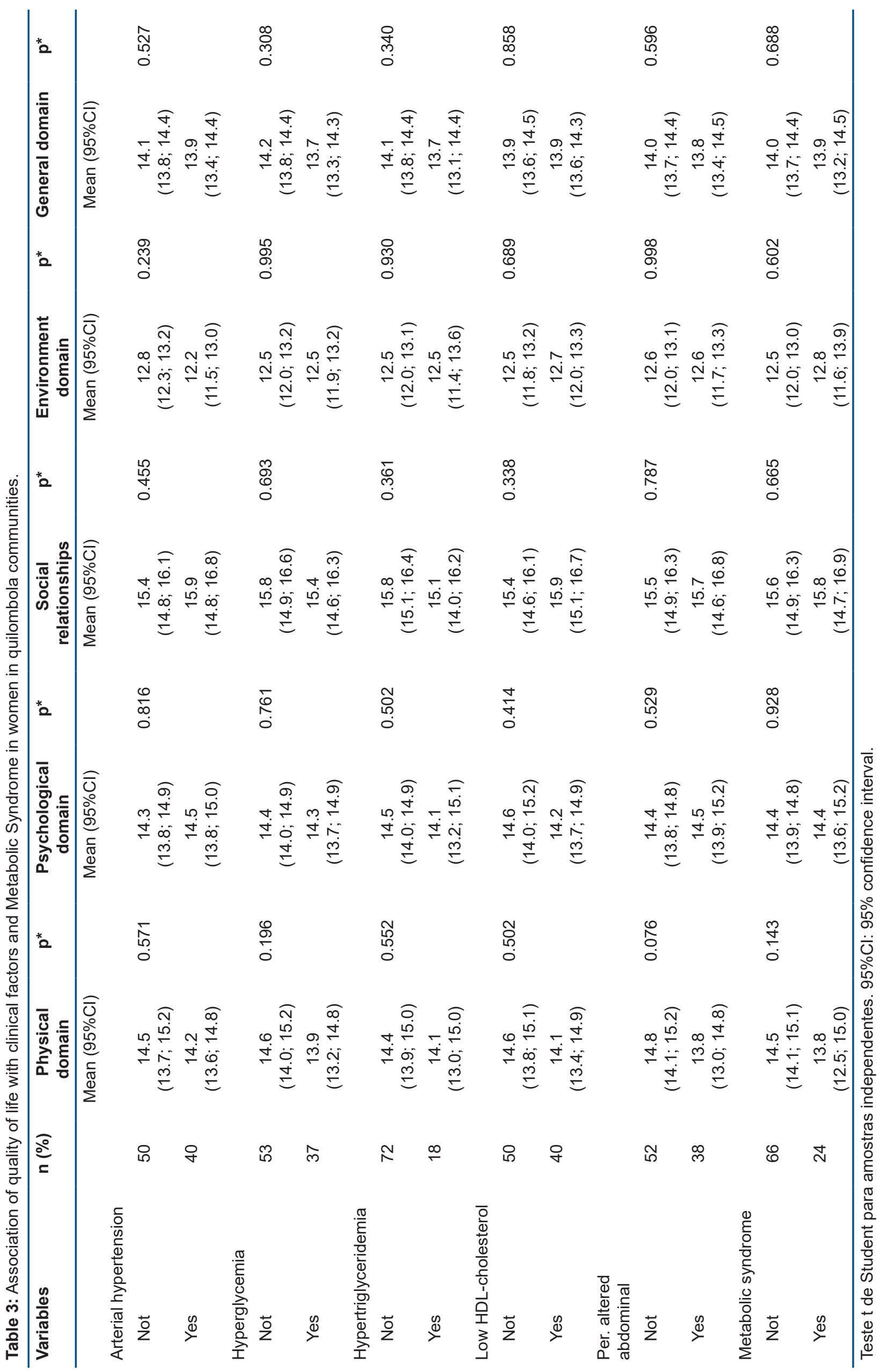




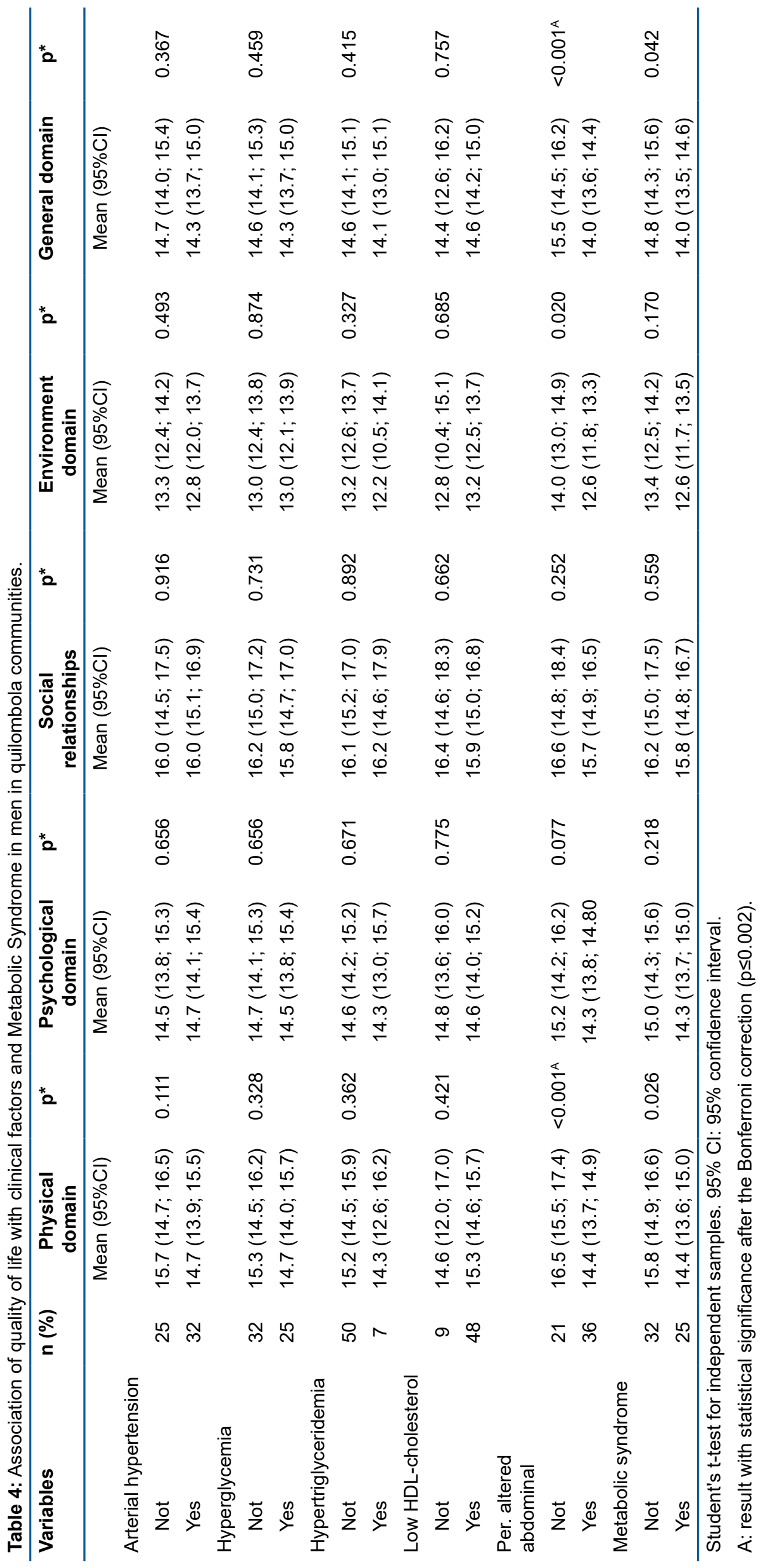




\section{DISCUSSION}

In this study, it was observed that in the quilombola populations studied there was an inverse association between the presence of MS and the Physical domain QoL score. This domain is composed of facets such as pain and discomfort, energy and fatigue, sleep and rest, mobility, daily life activities, dependence on mediation or treatment and work capacity, and facets that are related to the individual's functional capacity and autonomy levels, which are affected by the components of the MS by promoting influence on the physical health of quilombolas.

Among the risk factors, we observed that in the total population, an altered abdominal perimeter had an inverse association with the Physical and General QoL domains, and that MS had an inverse association with the Physical domain.

When stratified by sex, the altered abdominal perimeter in men was found to have an inverse association with the Physical, Environmental, and General QoL domains. MS showed an inverse association with the Physical and General QoL domains in men. However, in women there was no association between the risk factors studied and domains of quality of life.

It emphasizes the innovation of the study with the question, on the association of MS status with QoL, focusing on historically vulnerable communities and the verification of the component factors of MS by clinical exams, allowing good reproducibility and collaborating with future comparisons with other national communities. However, this study has some limitations. While this crosssectional epidemiological study found an association between MS and QoL among quilombolas, such results should be interpreted with caution because of the difficulty in establishing a causal relationship, since both concepts (QoL and MS) are complex and multifactorial.

In order to study the QoL and the health status of the quilombola population, it is necessary to understand their location, since they are usually located in rural areas with characteristics of geographic isolation, which exposes them to greater inequities in health ${ }^{24}$. In addition, it is necessary to take into account the epidemiological transition and urbanization that is taking place in the quilombola communities, which can lead to an increase in the burden of chronic diseases ${ }^{8,25}$.

In this study, lower QoL scores were found for the Environmental domain compared to the others, which may be related to the social vulnerability of the studied population, corroborating the findings of Braga et al. ${ }^{26}$. They found that the Environmental domain showed a lower mean score, a result related to the precarious leisure opportunities and the difficulties found in the physical environment ${ }^{27}$.

Our study also corroborates the findings of Almeida-Brasil et al. ${ }^{28}$, who studied four Basic Health Units (BHU) in the city of Belo Horizonte. They observed the importance of environmental conditions in QoL, highlighting the lower QoL of users of BHUs who were located in more vulnerable areas, investments and development policies, as well as deficiencies in health care and lack of transportation.
However, our findings disagree with those of Miranzi et al. ${ }^{29}$, who, when studying 30 individuals with hypertension and diabetes, and who were attended by a Family Health Team (FHT) in the state of Minas Gerais, Brazil, found that the Environment domain had high scores, being among those who collaborated most with the positive evaluation of QoL. In fact, the surrounding environment has been recurrently presented as a key factor for people's health and $\mathrm{QoL}^{30-33}$.

Studies on the relationship between the presence of chronic diseases and QoL of quilombola communities are rare. Oliveira et $a l .{ }^{34}$ carried out a study with 756 quilombolas from northern Minas Gerais, and showed that the presence of chronic disease was associated with negative self-perception of health. Their results partially coincide with those of this study, in that individuals with MS presented worse mean scores in the assertions of the WHOQOL-BREF questionnaire in relation to the Physical domain.

The study by Chen et $a l .{ }^{35}$, with 11,351 residents in rural areas of Liaoning Province in China, showed similar results, exhibiting associations between chronic diseases (obesity, hypertension and diabetes) and the four domains of QoL, with an emphasis on the Physical domain. Also, in the research by Amiri et al. ${ }^{12}$, a negative association between the components of MS and QoL was reported in an Iranian population, more specifically in the Physical domain, although in their findings a significant association was found only in females.

As evidenced in other studies, the association between MS and QoL may differ according to sex. Several reasons may explain different results between the sexes between communities. For example, while abdominal perimeter, HDL-cholesterol, and triglycerides are components that influence the relationship between MS and QoL among men, it is an important component for men; in the female, the abdominal perimeter seems to be the main contributing factor for this association, besides the influence of behavioral partners, such as age and smoking, which can also lead to this inequality ${ }^{11,12,36}$.

Of all assessed clinical factors, the abdominal perimeter was the only one associated with worse QoL scores, mainly in the Physical domain. It is interesting to note that this is the only "visible" factor to the participants, and it reflects unhealthy eating and living habits, also associated with the increase in the prevalence of MS in the world population ${ }^{37,38}$. According to the European Guidelines for atherosclerotic cardiovascular disease, other clinical factors are only perceptible through specific tests, and ignoring their correct status may mask the individual's actual state of health ${ }^{39-42}$.

In addition, research with other quilombola communities is necessary to strengthen the evidence base. Understanding the relationship between chronic diseases and QoL in quilombola communities is necessary to reduce social and health inequalities in historically vulnerable communities, by preparing health services and empowering members of such communities to cope with increasing lifestyle changes of the burden of chronic diseases and affect their QoL. 


\section{CONCLUSION}

In quilombolan communities in the Brazilian state of Tocantins, we observed a negative association between the altered abdominal perimeter of WHOQOL-REF participants and their QoL in both the Physical and General domains. Those with MS also had a negative association with the Physical domain. Stratifying by sex revealed that while men with an altered abdominal perimeter had an inverse association with the Physical, Environmental, and General domains, this was not observed in women. Furthermore, while MS was negatively associated with men's quality of life, MS does not interfere with the perception of QoL in the female population.

\section{Acknowledgements}

We thank the quilombola communities for their trust, support, and participation in this project.

\section{Funding}

This study was funded by Foundation for Research Support of the State of São Paulo in the modality Promotion Regular Program FAPESP (Process no 2015/02549-5).

\section{Conflict of interests}

The authors declare that they have no conflicts of interest with respect to the authorship and/or publication of this article.

\section{Availability of data and material}

The datasets generated and/or analyzed during the current study are not publicly available due to the fact that personal information is shared by the participants in their interviews, and participants may be identified from details they share in their interviews. However, they are available from the corresponding author on reasonable request.

\section{Authors' contributions}

LVAS, LSP, FA and ACGA designed the study and performed the data analysis. The ESM, FRPQ and LFAF were responsible for writing sections of the manuscript and assisting in the interpretation of the data and in the formulation of the argument. All authors read and approved the final manuscript.

\section{REFERENCES}

1. Fundação Cultural Palmares (FCP). Comunidades quilombolas certificadas 2015. [cited 2017 Jul 30] Available from: http://dados.gov.br/dataset/comunidades-quilombolas-certificadas

2. Freitas DA, Rabelo GL, Silveira JCS, Souza LR, Lima MC, Pereira MM, et al. Percepção de estudantes da área da saúde sobre comunidades rurais quilombolas no norte de Minas Gerais-Brasil. Rev CEFAC. 2013;15(4):941-6. DOI: https://dx.doi.org/10.1590/S1516-18462013000400023

3. Hogan VK, Rowley D, Bennett T, Taylor KD. Life course, social determinants, and health inequities: toward a national plan for achieving health equity for African American infants-a concept paper. Matern Child Health J. 2012;16(6):1143-50. DOI: https://dx.doi.org/10.1007/s10995-011-0847-0

4. Bezerra SMMS, Veiga EV. Quality of life among people with hypertension served in units of family health strategies. J Nurs UFPE. 2013;7(12):7055-63. DOI: https://dx.doi.org/10.5205/1981-8963-v7i12a12376p7055-7063-2013

5. Kabad JF, Bastos JL, Santos RV. Raça, cor e etnia em estudos epidemiológicos sobre populações brasileiras: revisão sistemática na base PubMed. Physis. 2012;22(3):895-918. DOI: http://dx.doi.org/10.1590/S0103-73312012000300004

6. Silva PS. Quilombos do Sul do Brasil: movimento social emergente na sociedade contemporânea. Rev Identidade. 2010;15(1):51-64.

7. Fleck MPA, Louzada S, Xavier M, Chachamovich E, Vieira G, Santos L, et al. Aplicação da versão em português do instrumento abreviado de avaliação da qualidade de vida "WHOQOL-bref". Rev Saúde Pública. 2000;34(2):178-83. DOI: http://dx.doi.org/10.1590/S0034-89102000000200012

8. Azevedo ALS, Silva RA, Tomasi E, Quevedo LA. Doenças crônicas e qualidade de vida na atenção primária à saúde. Cad Saúde Pública. 2013;29(9):1774-82. DOI: http://dx.doi.org/10.1590/0102-311X00134812

9. Zimmet P, Alberti KG, Kaufman F, Tajima N, Silink M, Arslanian S, et al. The metabolic syndrome in children and adolescents-an IDF consensus report. Pediatr Diabetes. 2007;8(5): 299-306. DOI: http://dx.doi.org/10.1111/j.1399-5448.2007.00271.x

10. Pontes LM, Amorim RJM, Lira PIC. Componentes da síndrome metabólica e fatores associados em adolescentes: estudo caso-controle. Rev AMRIGS. 2016;60(2):121-8.

11. Park SS, Yoon YS, Oh SW. Health-related quality of life in metabolic syndrome: The Korea National Health and Nutrition Examination Survey 2005. Diabetes Res Clin Pract. 2011;91(3):381-8. DOI: http://dx.doi.org/10.1016/j.diabres.2010.11.010

12. Amiri P, Deihim T, Hosseinpanah F, Barzin M, Hasheminia M, Montazeri A, et al. Diagnostic values of different definitions of metabolic syndrome to detect poor health status in Iranian adults without diabetes. Diabet Med. 2014;31(7):854-61. DOI: http://dx.doi.org/10.1111/dme.12443 
13. Margiotta DPE, Basta F, Dolcini G, Batani V, Navarini L, Afeltra A. The relation between, metabolic syndrome and quality of life in patients with Systemic Lupus Erythematosus. PloS One. 2017;12(11):e0187645. DOI: https://dx.doi.org/10.1371/journal.pone.0187645

14. Amaral GB, Pereira CMRB. Interseções entre território e identidade étnica: estudo sobre a comunidade quilombola Barra da Aroeira-TO. Rev Prod Acadêmica. 2016;2(1):65-74.

15. Marques KMCM, Reimer IR. The quilombola stream background on community of Nazareth Brejinho County-TO. Dissertação (Mestrado) - Pontifícia Universidade Católica de Goiás. Goiânia: 2014.

16. Souza LO, Teles AF, Oliveira RJ, Lopes MAO, Souza IA, Inácio VSS, et al. Triagem das hemoglobinas $\mathrm{S}$ e $\mathrm{C}$ e a influência das condições sociais na sua distribuição: um estudo em quatro comunidades quilombolas do Estado do Tocantins. Saúde Soc. 2013;22(4):1236-46. DOI: http://dx.doi.org/10.1590/S0104-12902013000400024

17. Development of the World Health Organization WHOQOL-BREF quality of life assessment. The WHOQOL Group. Psychol Med. 1998;28(3):551-8.

18. Pedroso B, Pilatti LA, Gutierrez GL, Santos CB, Picinin CT. Validação da sintaxe unificada para o cálculo dos escores dos instrumentos Whoqol. Conexões. 2011;9(1):130-56. DOI: https://dx.doi.org/10.20396/conex.v9i1.8637717

19. Vahedi S. World Health Organization Quality-of-Life Scale (WHOQOL-BREF): analyses of their item response theory properties based on the graded responses model. Iran J Psychiatry. 2010;5(4):140-53.

20. Veiga EV, Nogueira MS, Cárnio EC, Marques S, Lavrador MAS, Moraes AS, et al. Assessment of the techniques of blood pressure measurement by health professionals. Arq Bras Cardiol. 2003;80(1):89-93 . DOI: http://dx.doi.org/10.1590/S0066-782X2003000100008

21. Alves M.M. Desenvolvimento de um software para avaliação nutricional antropométrica utilizando Visual Basic For Applications. Monografia (Trabalho de Conclusão de Curso) - Universidade Federal do Rio Grande do Norte. Natal: 2016.

22. Guerrero GP, Beccaria LM, Trevizan MA. Procedimento operacional padrão: utilização na assistência de enfermagem em serviços hospitalares. Rev Latino-Am Enfermagem. 2008;16(6): 966-72. DOI: http://dx.doi.org/10.1590/S0104-11692008000600005

23. Associação Brasileira para o Estudo da Obesidade e da Síndrome Metabólica (ABESO). Diretrizes brasileiras de obesidade: 2016. 4.ed. São Paulo: ABESO, 2016.

24. Volochko A, Batista LE. Saúde nos quilombos. São Paulo: Instituto de Saúde, 2009; p.195-6.

25. Silva RJS, Smith-Menezes A, Tribess S, Rómo-PerezV, Virtuoso Júnior JS. Prevalência e fatores associados à percepção negativa da saúde em pessoas idosas no Brasil. Rev Bras Epidemiol. 2012;15(1):49-62. DOI: http://dx.doi.org/10.1590/S1415-790X2012000100005

26. Braga MCP, Casella MA, Campos MLN, Paiva SP. Qualidade de vida medida pelo Whoqol-bref: Estudo com idosos residentes em Juiz de Fora/MG. Rev APS. 2011;14(1):93-100.

27. Sousa LVA, Maciel ES, Quaresma FRP, Paiva LS, Fonseca FLA, Adami F. Descriptions of perceived quality of life of residents from a quilombo in north Brazil. J Hum Growth Dev. 2018;28(2):199-205. DOI: http://dx.doi.org/10.7322/jhgd.147239

28. Almeida-Brasil CC, Silveira MR, Silva KR, Lima MG, Faria CDCM, Cardoso CL, et al. Qualidade de vida e características associadas: aplicação do WHOQOL-BREF no contexto da Atenção Primária à Saúde. Cienc Saúde Coletiva. 2017;22(5):1705-16. DOI: http://dx.doi.org/10.1590/1413-81232017225.20362015

29. Miranzi SSC, Ferreira FS, Iwamoto HH, Pereira GA, Miranzi MAS. Qualidade de vida de indivíduos com diabetes mellitus e hipertensão acompanhados por uma equipe de saúde da família. Texto Contexto Enferm. 2008;17(4):672-9. DOI: http://dx.doi.org/10.1590/S0104-07072008000400007

30. Amarasinghe A, D'Souza A, Brown C, Oh H, Borisova T. The influence of socioeconomic and environmental determinants on health and obesity: a West Virginia case study. Int J Environ Res Public Health. 2009;6(8):2271-87. DOI: http://dx.doi.org/10.3390/ijerph6082271

31. Freitas DA, Caballero AD, Marques AS, Hernández CIV, Antunes SLNO. Saúde e comunidades quilombolas: uma revisão da literatura. Rev CEFAC. 2011;13(5):937-43. DOI: https://dx.doi.org/10.1590/S1516-18462011005000033

32. Santos VC, Boery EM, Pereira R, Rosa DOS, Vilela ABA, Anjos KF, et al. Socioeconomic and health conditions associated with Quality of life of elderly quilombolas. Texto Contexto Enferm. 2016;25(2): e1300015. DOI: http://dx.doi.org/10.1590/0104-07072016001300015

33. Neves LAT. Contributions in the field of Public Health for decision-making in health. J Hum Growth Dev. 2017;27(2):128-31. DOI: http://dx.doi.org/10.7322/jhgd.137515 
34. Oliveira LF, Rodrigues PAS. Circunferência de cintura: protocolos de mensuração e sua aplicabilidade prática. Nutrivisa Rev Nutr Vigilância Saúde. 2016;3(2):90-5. DOI: http://dx.doi.org /10.17648/nutrivisa-vol-3-num-2-h

35. Chen Y, Sun G, Guo X, Chen S, Chang Y, Li Y, et al. Factors affecting the quality of life among Chinese rural general residents: a cross-sectional study. Public Health. 2017;146:140- 7. DOI: https://dx.doi.org/10.1016/j.puhe.2017.01.023

36. Choo J, Jeon S, Lee J. Gender differences in health-related quality of life associated with abdominal obesity in a Korean population. BMJ open. 2014;4(1):e003954. DOI: http://dx.doi.org/10.1136/bmjopen-2013-003954

37. Lutsey PL, Steffen LM, Stevens J. Dietary intake and the development of the metabolic syndrome: The Atherosclerosis Risk in Communities study. Circulation. 2008;117(6):754-61. DOI: http://dx.doi.org/10.1161/CIRCULATIONAHA.107.716159

38. Mbugua SM, Kimani ST, Munyoki G. Metabolic syndrome and its components among university students in Kenya. BMC Public Health. 2017;17(1):909. DOI: http://dx.doi.org/10.1186/s12889-017-4936-x

39. Sahyoun NR, Jacques PF, Zhang XL, Juan W, McKeown NM. Wholegrain intake is inversely associated with the metabolic syndrome and mortality in older adults. Am J Clin Nutr. 2006;83(1):124-31. DOI: http://dx.doi.org/10.1093/ajcn/83.1.124

40. Wennberg M, Gustafsson PE, Wennberg P, Hammarström A. Poor breakfast habits in adolescence predict the metabolic syndrome in adulthood. Public Health Nutr. 2015;18(1):122-9. DOI: http://dx.doi.org/10.1017/S1368980013003509

41. Ribeiro BVS, Mendonça RG, Oliveira LL, Lima GS, Martins-Filho PRS, Moura NPR, et al. Anthropometry and lifestyle of children and adolescent in inland of Northeastern Brazil. J Hum Growth Dev. 2017;27(2):140-7. DOI: https://doi.org/10.7322/jhgd.119751

42. Piotrowicz K, Pałkowska E, Bartnikowska E, Krzesiński P, Stańczyk A, Biecek P, et al. Selfreported health-related behaviors and dietary habits in patients with metabolic syndrome. Cardiol J. 2015;22(4):413-20. DOI: http://dx.doi.org/10.5603/CJ.a2015.0020 


\section{Resumo}

Introdução: O estilo de vida das comunidades quilombolas vem sofrendo algumas modificações devido influência extra comunidade, afetando assim, os fatores ambientais e comportamentais relacionados com a Síndrome Metabólica (SM). No entanto, pouco se sabe sobre a influência da SM sobre a Qualidade de Vida (QV) de moradores de quilombos.

Objetivo: Estudar a associação entre SM e QV em comunidades quilombolas do norte do Tocantins.

Método: Estudo transversal com 147 adultos de cinco comunidades quilombolas localizadas no estado de Tocantins. Para mensurar a qualidade de vida, utilizou-se WHOQOL-bref. Pressão arterial, perímetro abdominal, glicemia em jejum, triglicerídeos e HDL-colesterol foram mensurados em exames clínicos. A presença da SM foi definida como a alteração de ao menos três desses aspectos clínicos. A associação dos componentes clínicos e a presença SM com a QV foi avaliada por meio do teste t de Student para amostras independentes, para a população total e estratificada por sexo.

Resultados: Dentre os fatores de risco, observa-se que o perímetro abdominal alterado apresenta associação inversa com os domínios Físico (15,2 vs. 14,0; $p=$ $0,002)$ e QV Geral (14,4 vs. 14,0; $p=0,045)$, e a SM com o domínio Físico (14,9 vs. $14,0 ; p=0,030)$ na população total. Ao estratificar por sexo, o perímetro abdominal alterado nos homens apresenta associação inversa com os domínios Físico (16,5 vs. 14,4; $p<0,001)$, Ambiental (14,0 vs. 12,6; $p=0,020)$ e QV Geral (15,5 vs. 14,0; $p<$ $0,001)$. A SM apresenta associação inversa com os domínios Físico (15,8 vs. 14,4; $\mathrm{p}=0,026)$ e QV Geral (14,8 vs. 14,0; 0,042) nos homens. E nas mulheres não há associação entre os fatores de risco estudados e domínios de qualidade de vida.

Conclusão: O status de SM apresentou-se negativamente associado a qualidade de vida do homem, destacando o perímetro abdominal, que influencia os domínios Físico e Geral da QV, porém, na população feminina a SM não interfere na percepção da QV. Entender a relação entre doenças crônicas e QV em comunidades quilombolas é necessário para reduzir inequidades em saúde de comunidades historicamente vulneráveis.

Palavras-chave: Quilombolas, qualidade de vida, síndrome metabólica, WHOQOLbref. 